Traktat Grzegorza z Nyssy $O$ tytułach psalmów powstał pół wieku wcześniej niż Augustynowe Enarrationes in Psalmos. Jego założeniem nie było jeszcze opracowanie chrystologii Psałterza, a jedynie troska o wprowadzenie ascetyczne do psalmów, obecnych już na trwałe w liturgii Kościoła i w pobożności prywatnej. Dziełko Grzegorza składa się z dwóch nierównych części, z których pierwsza zawiera wprowadzenie ogólne do traktatu, być może niedokończonego przez autora.

We wprowadzeniu Grzegorz wykłada swą hipotezę roboczą. Uważa on mianowicie, że pięć ksiąg Psałterza to szczeble drabiny prowadzącej ku doskonałości chrześcijańskiej, a tytuły psalmów zawarte w Biblii greckiej zawierają wskazówki dotyczące dążenia do cnoty i doskonałości. Część zasadnicza traktatu weryfikuje założenia wstępne, koncentrując się zwłaszcza na informacjach zawartych w nagłówkach psalmów. Całość dzieła można uważać za próbę wprowadzenia w literacką i teologiczną kompozycję pięcioksięgu Psałterza. Autor nie zamierza dawać wyczerpującej egzegezy każdego psalmu; chce jedynie zorientować swego czytelnika w kierunkach interpretacji całego zbioru.

Lekturę tego cennego dziełka Grzegorza z Nyssy ułatwia staranny i dokładny przekład dostarczony przez M. Przyszychowską. Ważne jest, że przekładu dokonała osoba od wielu lat studiująca słownictwo i teologię tego autora. Wiadomo, że przekład nie może być tylko poprawny językowo, ale musi głębiej wnikać w myśl autora dzieła, zwłaszcza gdy chodzi o literaturę starochrześcijańską. Polski czytelnik Grzegorza z Nyssy dostaje do rąk kolejne dzieło tego autora nie tylko w pięknej szacie graficznej, ale i w doskonałym przekładzie na język współczesny.

ks. Antoni Tronina - Lublin, KUL

\title{
Peter HEATHER, Odrodzenie Rzymu. Cesarze i papieże: bój o władzę nad chrześcijaństwem, tłum. Janusz Szczepański, Poznań 2014, Dom Wydawni- czy REBIS, ss. 515.
}

Peter Heather (ur. w 1960 r.) od stycznia 2008 r. jest profesorem historii okresu późnego antyku i wczesnego średniowiecza w prestiżowym londyńskim King’s College. Przed 2008 r. wykładał m.in. w oksfordzkim Worcester College, na Uniwersytecie Yale oraz na Uniwersytecie Londyńskim (dokładnie w University College London). Polskiemu Czytelnikowi Autor ten znany jest przede wszystkim z dwóch entuzjastycznie przyjętych na polskim rynku wydawniczym książek: Upadek Cesarstwa Rzymskiego oraz Imperia i barbarzyńcy, które zostały wydane w języku polskim przez poznańskie wydawnictwo Rebis kolejno w roku 2006 i 2010 (więcej na temat Autora i jego publikacji można znaleźć na oficjalnej stronie internetowej King's College London pod adresem: https://kclpure.kcl.ac.uk/ portal/peter.heather.html [dostęp: 1 IV 2014]; oraz np. na stronie: http://de.wikipedia.org/wiki/Peter_J._Heather [dostęp: 1 IV 2014]).

Recenzowana praca ukazała się pierwotnie w 2013 r. pod tytułem Restoration of Rome: Barbarian Popes \& Imperial Pretenders w znanym na całym świecie 
wydawnictwie Macmillan. Wkrótce też pozytywnie zrecenzował ją Conrad Leyser (zob. „History Today” 64 (2014) nr 2, 61-62; zdigitalizowany tekst tej recenzji jest dostępny także w internecie na stronie: http://www.historytoday.com/ blog/2014/01/restoration-rome [dostęp: 2 IV 2014]). Najnowsza książka P. Heathera jest swego rodzaju kontynuacją dwóch poprzednich jego prac (Upadek Cesarstwa Rzymskiego oraz Imperia i barbarzyńcy), choć należy przy tym zaznaczyć, że jest ona także pierwszą publikacją tego Autora, która dotyczy w dużej mierze historii Kościoła.

Odrodzenie Rzymu obejmuje w sumie 514 stron i składa się z 4 części (I. Kopia jedynego cesarstwa, s. 15-124; II. Zdobywca wielu krain, s. 125-233; III. Ojciec Europy, s. 235-329; IV. Ponowne przyjście, s. 331-444), które zostały poprzedzone Prologiem (s. 7-13) i domknięte Epilogiem (s. 445-454) o dwuznacznym tytule Ojciec chrzestny (część III). W każdej części książki zostały zamieszczone po 2 rozdziały, dzięki czemu Czytelnik otrzymuje spójny kompozycyjnie i tematycznie tekst, obejmujący okres od upadku ostatniego cesarza zachodniorzymskiego, Romulusa Augustulusa (ok. 460-507, cesarz 31 X 475 - 4 IX 476), do reformy Kościoła przeprowadzonej za pontyfikatu Innocentego III (ok. 1160/1161 - 16 VII 1216, papież od 8 I 1198).

Natomiast ze statystycznego punktu widzenia ta dosyć obszerna rozprawa (Prolog, 8 rozdziałów, Epilog) zawiera 420 stron samego tekstu, które zostały opatrzone łącznie 338 przypisami, co wskazuje, że średnio 0,804 przypisu przypada na jedną stronę.

Najkrótszą partią w całej pracy jest Prolog, obejmujący 7 stron tekstu i 4 przypisy $(0,571$ przypisu na stronę). Autor na przestrzeni tych kilku stron wprowadza Czytelnika w przedmiot swej rozprawy, który został ,zdefiniowany” następującymi słowami: „Podejmując narrację od wątku brzemiennego w skutki poselstwa Odoakra i przekazania insygniów cesarskich Konstantynopolowi, niniejsza kontynuacja Upadku cesarstwa rzymskiego opowiada historię trzech wielkich pretendentów, którzy z zadziwiającym powodzeniem starali się ożywić rzymskie tradycje mocarstwowe w zachodniej Europie: Teodoryka, Justyniana i Karola Wielkiego" (s. 12).

Najdłuższą zaś częścią pracy jest rozdz. 8: Habemus papam: papiestwo na starcie (s. 386-444), zawierający cztery podrozdziały: Jak hartowato sie papiestwo (s. 389-399); Pornokracja (s. 399-411); Papieże barbarzyńcy (s. 412-427); Harmonia niezgodnych kanonów (s. 428-444). Analiza ta obejmuje 59 stron i została udokumentowana 43 przypisami (0,728 przypisu na stronę). Autor przedstawia w tym rozdziale dzieje papiestwa tuż po upadku cesarskiej potęgi Karolingów, na gruncie której wyrosło z czasem, jak stwierdza P. Heather, drugie zachodnie Imperium Rzymskie (s. 385).

Pierwszy rozdział został zatytułowany Gens purpura (s. 17-70) i zajął Autorowi 54 strony, obejmujące 5 podrozdziałów (Getica, s. 19-26; Konstantynopol, s. 26-36; Singidunum, s. 36-48; Dyrrachium, s. 49-62; Rawenna, s. 62-70), zawierających 39 przypisów $(0,722$ przypisu na stronę). Tematem rozdziału jest postać 
pierwszego gockiego władcy zachodniej części cesarstwa rzymskiego z dynastii Amalów, czyli Teodoryka Wielkiego (ok. 454 - 20 VIII 526, król Ostrogotów od 475). W pierwszym podrozdziale Autor rozpoczyna analizę sylwetki ostrogockiego króla na podstawie jego konterfektu, pochodzącego z Getica Jordanesa (ok. VI w.), którą napisał on w Konstantynopolu około roku 550 (s. 19). W drugim z wymienionych podrozdziałów Autor kieruje uwagę Czytelnika na przyjazd ośmioletniego Gota do stolicy Bizancjum (ok. 463 r.), chcąc niejako odgadnąć, co mogło wówczas przykuć uwagę młodego Teodoryka. I jak słusznie zauważa P. Heather, prawdopodobnie półmilionowy w tym czasie Konstantynopol mógł przykuć jego uwagę głównie monumentalnymi budowlami, przy których wszystkie inne, jakie dotąd widział m.in. w Panonii, z której pochodził, musiały się mu „wydać karłowate” (s. 32). W trzecim i czwartym podrozdziale Autor zastanawia się nad motywami oraz okolicznościami przejęcia władzy przez Teodoryka nad Gotami panońskimi, których m.in. poprowadził zbrojnie pod mury Konstantynopola. Natomiast w piątym podrozdziale zostaje dokonana próba „rekonstrukcji przeprowadzki” Amala z Dyrrachium do postrzymskiej stolicy, Rawenny, która to rekonstrukcja jest, w opinii P. Heathera, zadaniem trudnym z powodu braku dostatecznie szczegółowych informacji źródłowych na ten temat (s. 62).

Rozdział drugi, Filozof w purpurze (s. 71-124), omawia również na przestrzeni 54 stron, podzielonych na 6 podrozdziałów i ,wmocnionych” 48 przypisami $(0,888$ przypisu na stronę), kwestię odbudowy zachodniej części Cesarstwa Rzymskiego przez Teodoryka, który do 493 r. zdołał podbić niemal całą Italię (s. 70). Podrozdział pierwszy omawianej części książki został zatytułowany Kasjodor (s. 72-81). Autor analizuje w nim postać gockiego władcy z perspektywy jego zainteresowań filozoficznych, posiłkując się przy tym informacją źródłową, zawartą w zbiorze pism urzędowych pt. Variae, które zostały zebrane i spisane właśnie przez Kasjodora (ok. 485-585). Jak podkreśla P. Heather, jest to „[...] podstawowe źródło wiadomości o Teodoryku filozofie rojącym o ratowaniu przed rozpadem rzymskiego Zachodu, coraz bardziej barbarzyńskiego i ogarniętego przemocą" (s. 72). Drugi podrozdział, Być Rzymianinem (s. 81-88), jest swego rodzaju odautorską próbą znalezienia odpowiedzi na pytanie: dlaczego Teodoryk tak bardzo dążył do restauracji tzw. romanitas? W rezultacie przeprowadzonych analiz, Autor stwierdza enigmatycznie, iż mogło to po prostu wypływać z powziętej przez gockiego władcę ,inteligentnej strategii”, która miała „bardzo praktyczne zastosowania” (s. 81). Dwutysięczny rok gockiej historii (s. 88-100) to temat trzeciego podrozdziału, w którym P. Heather na 13 stronach stara się rozszyfrować sens słów Jordanesa zawartych w Getica, a mówiących o jubileuszu dwutysiąclecia istnienia królestwa gockiego, który przypadał na okres panowania Teodoryka w Italii (s. 89). W kolejnym podrozdziale, noszącym tytuł Semper Augustus (s. 100-109), zostały przedstawione ambicje imperialne Teodoryka oraz jego problemy związane $\mathrm{z}$ brakiem męskiego potomka (s. 102). Trudno w tym miejscu nie zgodzić się z Autorem, który stwierdza m.in., że ,niepewna sukcesja była największym z problemów w polityce wewnętrznej świata starożytnego i średniowiecznego, powodującym 
więcej konfliktów niż wszystkie pozostałe razem wzięte" (s. 103). Ostatnie dwa podrozdziały to Śmierć w Rawennie (s. 109-119) i Rzymskie imperium Gotów (s. 119-124). Dotyczą one głównie ostatnich lat panowania Teodoryka oraz przyczyn rozpadu jego imperium. P. Heather informuje w nich Czytelnika w szczególności o konflikcie ostrogockiego władcy ze znanym filozofem i zarządcą urzędów na dworze Amala, Boecjuszem (ok. 480-524/525) (s. 109-114); o kwestii sukcesji tronu Teodoryka po zbyt wczesnej śmierci jego zięcia Eutaryka, który zmarł ok. 522/523 r. (s. 114); oraz o prześladowaniu chrześcijan nienicejskich przez cesarza Justyna I (ok. 450 - 1 VIII 527, cesarz od 9 VII 518) (s. 117).

Trzeci rozdział nosi tytuł $Z$ bożego przyzwolenia (s. 127-177) i otwiera druga część książki (Zdobywca wielu krain). Zajmuje on 51 stron, na których znajdują się 4 podrozdziały (Anekdota, s. 130-139; Corpus Iuris Civilis, s. 139-154; Nika, s. 154-167; Do Ad Decimum i dalej, s. 167-177) oraz 41 przypisów $(0,803$ przypisu na stronę). Autor skupia się w nim na analizie źródłowej sylwetki bizantyńskiego cesarza Justyniana I Wielkiego (11 V 483 - 13 XI 565, cesarz od 1 VIII 527). Pierwszy podrozdział zawiera informacje na temat znanego dziejopisa na dworze Justyniana, Prokopiusza z Cezarei (ok. 490-562), którego P. Heather określa prześmiewczo mianem „,autora-wazeliniarza” (s. 133). W tej części swej pracy Twórca Odrodzenia Rzymu stara się dociec z perspektywy współczesnego historyka, na ile jest wiarygodna relacja Prokopiusza, zawarta w napisanej przez niego Historii sekretnej. Drugi i trzeci z wymienionych podrozdziałów dotyczą głównie reformy prawa rzymskiego w czasach Justyniana oraz zbrojnego konfliktu cesarza z Persją, a także powstania Nika, które wybuchło we wtorek 13 XI 532 r. (s. 155). Czwarty podrozdział opisuje podbój Kartaginy przez dowódcę wojsk Justyniana, Belizariusza (ok. 500-565), który odbił to miasto z rąk Wandalów w wyniku dwóch kluczowych bitew, które stoczono najpierw pod osadą Ad Decimum 13 IX 533 r., a następnie pod Trikamarum 15 XII tego samego roku (s. 167-171).

Rozdział czwarty, Nawa na wzburzonych wodach (s. 178-233), jest dalszą częścią analizy postaci cesarza Justyniana I Wielkiego. Jest to rozdział, który posiada najwięcej odnośników (bo aż 52) i ich „gęstość” wynosi 0,928 przypisu na stronę. Autor rozpatruje w nim na 56 stronach, podzielonych na pięć podrozdziałów, w jaki sposób za panowania Justyniana mogło dojść do sytuacji, w której cesarstwo znalazło się w swego rodzaju kryzysie geopolitycznym, stając się jednocześnie łatwym łupem dla najeźdźców z zewnątrz. Pierwszy podrozdział został zatytułowany Zmierz Gotów (s. 179-192) i dotyczy zarówno przebiegu oraz skutków wyprawy Belizariusza na podbój gockiej Italii w latach 536-540, jak i tzw. drugiej wojny italskiej, toczącej się w latach 540-556. W podrozdziale drugim, o wymownym tytule Pyrrusowy triumf? (s. 192-206), Autor stara się dokonać całościowej oceny polityki podbojów Justyniana na Zachodzie. W trzecim podrozdziale, $O$ stoniach $i$ sofach (s. 206-216), P. Heather próbuje odpowiedzieć na pytanie: „dlaczego po śmierci Justyniana Bizancjum nie zdołało utrzymać kontroli nad resztą Półwyspu Apenińskiego" (s. 206). Natomiast w podrozdziale czwartym, Siedem miast Azji (s. 216-229), zwrócono uwagę na losy obszarów bałkańskich i bliskowschodnich 
tuż po śmierci cesarza w 565 r., a także na eskalację napięć politycznych między Bizancjum i Persją za panowania jego następcy, Justyna II (ok. 520 - 5 X 578, cesarz od 15 XI 565). Zwieńczeniem omawianego rozdziału jest krótki ustęp, zatytułowany Dziedzictwo (s. 229-233), w którym zostały zawarte ogólne wnioski podsumowujące. Ich charakter dobrze oddaje teza Autora Odrodzenia Rzymu, iż po śmierci Justyniana I Wielkiego „bieg historii cesarstwa wschodnio-rzymskiego zasadniczo zmieniło pojawienie się żywiołu islamskiego" (s. 229).

Następny rozdział wprowadza Czytelnika w tematykę trzeciej części książki (Ojciec Europy). Przedmiotem rozważań Autora w tym rozdziale jest Boże Narodzenie $A D 800$ (s. 237-279), opracowane na 43 stronach i udokumentowane 31 przypisami ( 0,720 przypisu na stronę), podczas którego Karol Wielki (ok. 2 IV 742/747/748 - 28 I 814) otrzymał koronę cesarską z rąk papieża Leona III (ok. 750 - 12 VI 816, papież od 27 XII 795). Czytelnik znajdzie w nim cztery podrozdziały (Lwy, niedźwiedzie i pośledniejsze drapieżniki, s. 238-248; Młot Franków, s. 248261; Dar Karola Wielkiego, s. 261-275; Niedole papieża Leona III, s. 275-279), w których zawarto informacje na temat panowania Chlodwiga (ok. 481/482 - 27 XI 511) nad zjednoczonymi przez siebie ludami frankijskimi; rozwoju kariery politycznej Karola Młota (ok. 688 - 22 X 741); strategii geopolitycznej papiestwa w dobie koronacji Karola Wielkiego na cesarza; oraz celów politycznych samej ceremonii koronacyjnej, widzianej zwłaszcza z perspektywy papieża Leona III. Zatem ta ostatnia część piątego rozdziału odnosi się do historycznych okoliczności, które złożyły się na proces odrodzenia zachodniego Cesarstwa Rzymskiego pod berłem Karola Wielkiego.

Rozdział szósty, Równowagi nie da się utrzymać (s. 280-329), obejmuje 50 stron tekstu i 29 przypisów (0,580 przypisu na stronę). Celem dociekań Autora na przestrzeni pięciu podrozdziałów, na które podzielono tę część rozprawy, są „dalsze dzieje cesarstwa zrodzonego z wielkości króla Franków oraz kłopotów Leona III i [to] jak sobie radzili następcy ich obu" (s. 279). Ojciec chrzestny (część I) (s. 282-293), to tytuł pierwszego podrozdziału. Autor przedstawia w nim sposób sprawowania władzy przez Karola Wielkiego oraz postać Ludwika I Pobożnego (ok. 778 - 20 VI 840, cesarz od 28 I 814), którego czyny, jak stwierdza P. Heather, paradoksalnie nie współgrały z jego historycznym przydomkiem (s. 284). Drugi podrozdział, Gorszych rzezi nie bywało (s. 293-304), przedstawia chaos w jaki popadł świat karoliński w 2 poł. IX w., gdy cesarstwo Karola Wielkiego zostało oficjalnie podzielone na trzy części w wyniku postanowień traktatu z Verdun w roku 843 (s. 296). Trzeci podrozdział został zatytułowany Koniec z podatkami (s. 304-315) i dotyczy polityki fiskalnej cesarstwa Karolingów w IX i X w., która doprowadziła do ugruntowania pozycji Karola Wielkiego i Ludwika I Pobożnego jako niezależnych władców dynastycznych. Następny podrozdział to Pierwsza Rzesza (s. 315-327). Autor zwraca w nim szczególną uwagę na główną przyczynę zahamowania ekspansji terytorialnej imperium Karola Wielkiego, będącej podstawowym źródłem dochodów jego cesarstwa, wręcz ,substytutem powszechnego opodatkowania” (s. 324). P. Heather konstatuje słusznie, że „ekspansję Karolingów 
zahamowała presja ze strony zmilitaryzowanej elity, dla której ewentualne łupy, okupowane krwią i wysiłkiem, znacznie straciły na atrakcyjności wobec korzyści ze sprzedawania poparcia na miejscu, bez konieczności przeprawiania się za Łabę czy wspinaczki na pirenejskie przełęcze" (s. 326). Rozdział szósty zamyka trzystronicowy podrozdział: Narodziny Europy i kres cesarstwa (s. 327-329), w którym Autor dokonuje całościowego podsumownia wywodów zawartych w trzeciej części recenzowanej pracy, która, jak już wspomniano wyżej, nosi tytuł Ojciec Europy.

Siódmy rozdział został zatytułowany Karol Wielki i papież Leon III (s. 333385). Rozpoczyna on analizę zagadnień w ostatniej, czyli czwartej części rozprawy (Ponowne przyjście). 59 stron tekstu zostało tutaj uzupełnionych 43 przypisami $(0,728$ przypisu na stronę) oraz podzielonych na cztery podrozdziały (Cesarze i patriarchowie, s. 337-350; Królowie i biskupi, s. 350-366; Ojciec chrzestny (część II), s. 366-380; Chrześcijaństwo za dni naszych?, s. 380-385). W tym rozdziale Czytelnik znajdzie m.in. informacje nt. kompetencji cesarza i papieża w sprawach kościelnych, w pierwszych wiekach istnienia chrześcijaństwa. W tym kontekście Autor stawia dość odważną tezę, w myśl której „rzeczywiste rozwiązania teologiczne zależały od woli cesarzy, którzy zwoływali sobory, budowali koalicje niezbędne do przeforsowania odpowiadających im idei, a potem konsekwentnie egzekwowali ich wdrażanie" (s. 346). P. Heather analizuje także przyczyny wprowadzenia w Bizancjum ikonoklazmu za panowania cesarza Leona III Izauryjczyka (ok. 680 - 18 VI 741, cesarz od 25 III 717) (s. 357). Autor odnosi się także do programu reformy chrześcijaństwa za panowania Karola Wielkiego, którego intencją było dokonanie całościowej transformacji Kościoła zachodniego (s. 370375). Tematem rozważań jest również tzw. renesans karoliński (s. 376-380) oraz rezultaty karolińskiego projektu correctio, mającego na celu podniesienie dyscypliny kościelnej m.in. przez wzmocnienie władzy metropolitów (s. 380-385).

$\mathrm{Na}$ temat ósmego rozdziału wspomniano już wcześniej. Jednak w kontekście dwóch ostatnich rozdziałów warto dodać, że obraz papiestwa i Państwa Kościelnego, jaki się z nich wyłania jest niezwykle krytyczny, wręcz hiperkrytyczny. P. Heather przyrównuje bowiem urząd papieski z czasów średniowiecznej infamii do „dziwki” lub „dojnej krowy” (s. 411, lin. 3 od dołu). Autor stara się też usilnie udowodnić tezę, w myśl której papiestwo jako takie było swego rodzaju dynastią, która przetrwała tak długo tylko i wyłącznie dzięki subsydiowaniu Państwa Kościelnego przez skarbiec cesarski, stając się niejako samofinansującą się instytucją dopiero w okresie późnego średniowiecza. Krytyka P. Heathera jest tu prowadzona $\mathrm{w}$ duchu ortodoksyjnego anglikanizmu, choć sam Autor stara się oficjalnie nie popadać w konfesjonalizm jako taki.

Przedstawiony wyżej rdzeń recenzowanej książki został uzupełniony kilkoma ważnymi ,apendyksami”. Pierwszym z nich jest obszerna bibliografia, która składa się z Tekstów źródtowych (s. 484-486) oraz Bibliografii opracowań (s. 487504). Teksty źródtowe zawierają 52 pozycje, z czego część (12 pozycji) została uzupełniona o informacje na temat istniejących polskich przekładów. W Bibliografii zamieszczono łącznie 422 pozycje, wśród których znalazły się także 
22 opracowania polskojęzyczne (jest to 5,213\% całości), które co prawda nie są bezpośrednio cytowane przez Autora, ale stanowią swego rodzaju kolejne uzupełnienie, będące jednocześnie informacją bibliograficzną dla polskiego Czytelnika. Większość pozycji w Bibliografii to opracowania w języku angielskim, lecz można znaleźć tam również 28 pozycji w języku łacińskim (choć jest to rozwiązanie zupełnie niezrozumiałe, o czym w dalszej części recenzji), 19 w języku francuskim, $18 \mathrm{w}$ języku niemieckim, 2 opracowania po hiszpańsku i 1 po włosku (w sumie $16,113 \%$ całości). Ponadto wydawnictwo Rebis dodało Wybór bibliografii polskojęzycznej (s. 505), w którym widnieje w sumie 20 opracowań. Drugim istotnym „dodatkiem” jest Indeks osobowy (s. 506-510) oraz Indeks geograficzny (s. 511-512). Trzecim uzupełnieniem rozważań Autora jest 29 kolorowych ilustracji, których spis (Ilustracje) podano na s. 513-514. Ilustracje te zostały zamieszczone w formie dwóch wkładek między stroną 192 a 193 oraz 352 a 353 . Wreszcie czwartym elementem dopełniającym pracę P. Heathera są czaro-białe mapy, których wykaz (Mapy) zamieszczono na s. 515. Map tych jest 16. Wśród nich znalazła się również rycina przedstawiająca drzewo genealogiczne dynastii Amalów (s. 24). Tego typu „dodatki” zawsze znacząco wzbogacają teksty książek, publikowanych przez poznańskie wydawnictwo Rebis i są na polskim rynku wydawniczym jego swoistym znakiem rozpoznawczym. Sam P. Heather dodał jeszcze do tekstu pewien akcent osobisty w postaci Podziękowania (s. 455-456), adresowanego do osób, które przyczyniły się do powstania Odrodzenia Rzymu.

W polskim przekładzie pracy P. Heathera nie uniknięto niestety pomyłek i błędów. Do najbardziej ewidentnych można zaliczyć brak identyfikacji zawartych w książce cytatów źródłowych. Pierwszy z nich znajduje się na s. 27 (lin. 10-11 od góry) i dotyczy słów Konstantyna I Wielkiego (ok. 27 II 272 - 22 V 337, cesarz od 25 VII 306): „Serdika [...] jest moim Rzymem” (łac. Roma mea Sardica est). Cytat ten pochodzi z: Anonymus post Dionem (= Dionis continuatio), w: Fragmenta Historicorum Graecorum, ed. C. Müller, t. 4, Paris 1868, 199, fr. 15. Natomiast na s. 334 (lin. 13 od góry) został umieszczony cytat z Nowego Testamentu, a dokładniej z Ewangelii św. Mateusza: „Ty jesteś Chrystus, Syn Boga żywego”, przy którym brak koordynatów biblijnych. Tymczasem jest to cytat pochodzący z: Mt 16, 16. Z kolei na s. 352 (lin. 11 od dołu) zostały zacytowane sparafrazowane słowa papieża Grzegorza I Wielkiego (ok. 540 - 12 III 604, papież od 3 IX 590): „Non Angli, sed Angeli”. Cytat można znaleźć w: Beda Venerabilis, Historia ecclesiastica gentis Anglorum II 1, 18-20, ed. P. Delaveau: Bède le Vénérable, Histoire ecclésiastique du peuple anglais, SCh 489, Paris 2005, 286. Następnym niezidentyfikowanym quasi-cytatem są słowa średniowiecznego kronikarza Reginalda z Prüm († ok. 915): „wykreować się na władcę świata”, które zamieszczono na s. 398 (lin. 4 od dołu). Pochodzą one z: Regino Prumiensis, Chronicon cum Continuatione Treverensi, MGH Scriptores rerum Germanicarum 50, 94: „Regibus ac tyrannis imperavit [Nicolaus I, papa] eisque ac si dominus orbis terrarum auctoritate prefuit”. Ostatni zaś cytat znajduje się na s. 449 (lin. 14-15 od dołu), gdzie zacytowano bez odsyłacza słowa Józefa Stalina (18 XII 1878 - 5 III 1953): 
„Papież? A ile on ma dywizji?”. Tymczasem jest to cytat z: W.S. Churchill, Druga wojna światowa, thum. K.F. Rudolf, t. 1, Gdańsk 1994, 147.

Inny problem to kwestia „dziwolagów” językowych. I tak na s. 12 (lin. 17 od dołu) użyto terminu: „outsiderzy”, który powstał wskutek spolszczenia angielskiego terminu outsider (por. s. 421 (lin. 3 od góry): „outsiderem”). Podobne rozwiązanie zastosowano na s. 151 (lin. 11 od dołu), gdzie użyto określenia: „establishmencie” (por. s. 223 (lin. 1 od dołu): „establishmentu”). Następny przykład znajduje się na s. 171 (lin. 4 od góry), gdzie widnieje słowo: „blitzkriegu” (por. s. 180, lin. 1 od góry). Podobny przypadek znajduje się na s. 278 (lin. 6-7 od góry), gdzie można przeczytać: „bon motem”. Natomiast na s. 316 (lin. 10 od dołu) można znaleźć kolejny spolonizowany termin pochodzenia angielskiego, czyli: „spin-doktorów”. Tymczasem poprawność językowa wymaga, aby unikać stosowania tego typu makaronizmów. Jeśli zaś chce się je mimo wszystko stosować, należy wziąć takie terminy w cudzysłów tak, jak uczyniono na s. 72 (lin. 11 od góry) ze spolszczeniem anglojęzycznego pojęcia spin doctor czy na s. 254 (lin. 2 od dołu) z pojęciem front man.

Z kolei na s. 181 (lin. 14-16 od dołu) zostały podane konkretne miasta (,Auximum (Osimo)”, „Kluzjum (Chiusi)”, „Urviventus (Orvieto)”, „Tudera (Todi)”, „Petra”, „Urbinus (Urbino)”, „Cesena”, „Montefertro”), które w 538 r. były areną rozgrywających się wówczas wydarzeń historycznych, związanych z wyprawą i podbojem Italii przez Belizariusza. Niestety część z wymienionych miast, a dokładnie „Kluzjum (Chiusi)”, „Urviventus (Orvieto)”, „Tudera (Todi)” i „Montefertro", nie została uwzględniona na mapie nr 9 (Podbój Italii, s. 186 - sama mapa nie ma numeru, jest on dopiero w spisie map na s. 515), choć odsyłacz w tekście wskazuje, że miasta te zostały tam zaznaczone. Podobna sytuacja ma miejsce na s. 317 (lin. 13-14 od dołu), gdzie nie zostały zaznaczone na mapie nr 15 (Główne jednostki polityczne zachodniego chrześcijaństwa ok. 1000 r., s. 319 - sama mapa nie ma numeru, jest on dopiero w spisie map na s. 515) m.in. „Węgry” i „Ruś zachodnia" pomimo, że w tekście jest odnośnik (s. 315, lin. 13 od dołu) wskazujący, że te państwa powinny być uwzględnione na wspomnianej mapie wraz z „Czechami” i „Polską".

Jeszcze inny problem stanowią wykazy bibliograficzne. Zostały one podzielone na Teksty źródlowe i Bibliografię. Wynika stąd logiczny wniosek, że Bibliografia powinna zawierać wyłącznie literaturę pomocnicza, czyli opracowania. Tymczasem, jak już wyżej wspomniano, zostało tutaj zamieszczonych 28 pozycji książkowych w języku łacińskim, które powinny były znaleźć się w Tekstach źródłowych. Ponadto niektóre ich opisy bibliograficzne zawierają pewne nieścisłości: 1) (s. 488, lin. 1-2 od góry) jest: „Bethmann, L., G. Waitz (red.) (...) MGH Scriptores rerum Germanicarum”, powinno być: „Bethmann, L., G. Waitz (wyd.) (...) MGH Scriptores rerum Germanicarum 48"; 2) (s. 491, lin. 17 od góry) jest „De Boor, C., P. Wirth (red.)”, powinno być: „Boor, C. de, P. Wirth (wyd.)”; 3) (s. 491, lin. 20 od dołu) jest: „Dessau, H.”, powinno być: „Dessau, H. (wyd.)”; 4) (s. 491, lin. 15 od dołu) jest: „Dindorf, L. (red), Chronicon Paschale, Bonn 
1832”, powinno być: „Dindorf, L. (wyd.), Chronicon Paschale, Corpus scriptorum historiae Byzantinae, Bonn 1832”; 5) (s. 491, lin. 8 od dołu) jest: „Duchesne, L.”, powinno być: „Duchesne, L. (wyd.)”; 6) (s. 491, lin. 2 od dołu) jest: „Dümmler, E., Liudprandi episcopi Cremonensis Opera omnia, Hanower 1877", powinno być: „Dümmler, E. (wyd.), Liudprandi episcopi Cremonensis Opera omnia, MGH Scriptores rerum Germanicarum 41, Hanower 1877"; 7) (s. 492, lin. 11-12 od góry) jest: „Engelbrecht, A., Fausti Reiensis Praeter sermones pseudo-eusebianos opera: accedunt Ruricii Epistulae, Mediolan 1891”, powinno być: „Engelbrecht, A. (wyd.), Fausti Reiensis Praeter sermones pseudo-eusebianos opera: accedunt Ruricii Epistulae, Corpus scriptorum ecclesiasticorum Latinorum 21, Wiedeń 1891”; 8) (s. 493. lin. 6-7 od góry) jest: „Gilchrist, J., Diversorum patrum sententie sive Collectio in LXXIV titulos digesta, Watykan 1973", powinno być: „Gilchrist, J. (wyd.), Diversorum patrum sententie sive Collectio in LXXIV titulos digesta, Monumenta iuris canonici. Series B: Corpus collectionum 1, Watykan 1973”; 9) (s. 494, lin. 4 od góry) jest: „Hanower 1892”, powinno być: „Berlin 1892”; 10) (s. 494, lin. 18 od góry) jest: „Hartel, W., Magni Felicis Ennodii Opera omnia, Wiedeń 1882”, powinno być: „Hartel, W. (wyd.), Magni Felicis Ennodii Opera omnia, Corpus scriptorum ecclesiasticorum Latinorum 6, Wiedeń 1882"; 11) (s. 495, lin. 14-15 od góry) jest: „Heinischen, F.A. (1868-70). Eusebii Pamphili Scripta Historica, Lipsk 1868-1870”, powinno być: „Heinischen, F.A. (wyd.), Eusebii Pamphili Scripta historica, t. 1-3, Lipsk 1868-1870"; 12) (s. 496, lin. 14 od góry) jest: „Keydell, R., Agathiae Myrinaei Historiarum libri quinque, Berlin 1967”, powinno być: „Keydell, R. (wyd.), Agathiae Myrinaei Historiarum libri quinque, Corpus fontium historiae Byzantinae 2: Series berolinensis, Berlin 1967”; 13) (s. 496, lin. 21 od dołu) jest: „Kreuger, P. (red.), Corpus Iuris Civilis, Berlin 1877”, powinno być: „Krueger [lub Krüger], P. (wyd.), Corpus Iuris Civilis, t. 1-2, wyd. 2, Berlin 1877”; 14) (s. 496, lin. 20 od dołu) jest: „Kreuger, P., Th., Mommsen, Codex Theodosianus, Berlin 1928”, powinno być: „Krueger [lub Krüger], P., Th., Mommsen (wyd.), Codex Theodosianus, Berlin 19??”. Były trzy wydania kodeksu (wyd. $1=1905$, wyd. $2=1954$, wyd. $3=1962$ ), ale żadne w roku 1928; 15) (s. 496, lin. 18-19 od dołu) jest: „Krusch, B., Fredegar Chronicorum libri VII cum continuationibus, MHG scriptores rerum Merivingicarum 2, Hanower 1888”, powinno być: „Krusch, B. (wyd.), Fredegarii et aliorum chronica, MHG Scriptores rerum Merivingicarum 2, Hanower 1888"; 16) (s. 496, lin. 14-15 od dołu) jest: „Krusch, B., W. Levison (red.), Gregory of Tours Historiae, MGH scriptores rerum Merivingicarum 1.1, Berlin 1951”, powinno być: „Krusch, B., W. Levison (wyd.), Gregorii Turonensis libri Historiarum X, MGH Scriptores rerum Merivingicarum 1.1, Hanower 1951"; 17) (s. 496, lin. 12-13 od dołu) jest: „Kurze, F. (red.), MGH SRG, Reginonis abbatis Prumiensis Chronicon, Hanower 1890”, powinno być: „Kurze, F. (wyd.), Reginonis abbatis Prumiensis Chronicon cum Continuatione Treverensi, MGH Scriptores rerum Germanicarum 50, Hanower 1890”; 18) (s. 496, lin. 2-3 od dołu) jest: „Leo, G., Venantius Fortunatus, Opera Poetica. MGH auctores antiquissimi 4.1, Berlin 1881”, powinno być: „Leo, 
F. (wyd.), Venantii Fortunati Opera poetica. MGH Auctores antiquissimi 4.1, Berlin 1881"; 19) (s. 498, lin. 15 od dołu) jest: ,auctores antiquissimi 5.1”, powinno być: „Auctores antiquissimi 5.1”; 20) (s. 498, lin. 11-13 od dołu) jest: „,- (wyd.), (1894a). Cassiodori... Variae: I. Epistulae Theodoricianae variae. II. Acta synhodorum habitarum Romae. III. Cassiodori Orationum reliquiae, red. L. Traube. MGH auctores antiquissimi 12, Berlin 1894”, powinno być: ,-(wyd.), Cassiodori Senatoris Variae: I. Epistulae Theodoricianae variae. II. Acta synhodorum habitarum Romae. III. Cassiodori Orationum reliquiae, MGH Auctores antiquissimi 12, Berlin 1894”; 21) (s. 498, lin. 10 od dołu) jest: ,- (wyd.), (1894b). Chronica Minora, t. 2, auctores antiquissimi, Berlin 1894", powinno być: „-- (wyd.), Chronica Minora, t. 2, MGH Auctores antiquissimi 11, Berlin 1894"; 22) (s. 499, lin. 4 od góry) jest: „Muller, C., Fragmenta Historicorum Graecorum, t. 4-5, Paryż 1868/1870”, powinno być: „Müller, C., Fragmenta Historicorum Graecorum, t. 4-5, Paryż 1868-1870”; 23) (s. 499, lin. 19 od dołu) jest: „Niebuhr, B.G. (red.), Theophanes Chronographia, Bonn 1839-1841”, powinno być: „Classen J. (wyd.), Theophanis Chronographia, t. 1-2, Corpus scriptorum historiae Byzantinae, Bonn 1839-1841”; 24) (s. 501, lin. ) jest: „Schenk1, H. i in. (red.), Themistii Orationes, Lipsk 1965-1974”, powinno być: „Schenkl, H. i in. (wyd.), Themistii Orationes, t. 1-3, Lipsk 1965-1974”; 25) (s. 502, lin. 12-13 od dołu) jest: „Stewart, H.F. i in., Boethius: Tractates, De consolatione philosophiae, Cambridge 1918", powinno być: ,Boethius: The theological tractates, with an English translation by H.F. Stewart, E.K. Rand and S.J. Tester, The Loeb Classical Library 74, Cambridge 1918".

Same Teksty źródłowe pozostawiają także wiele do życzenia, ponieważ są redakcyjnie niedopracowane i należałoby przy następnym polskim wydaniu tej książki solidnie popracować nad jej stroną redakcyjną. M.in. na s. 486 (lin. 4-5 od góry) jest: „Wyd polskie: Teofanes Wyznawca, Kronika w: Greckie i łacińskie źródła do najstarszych dziejów Słowian, cz. I, przeł. M. Plezia, Poznań-Kraków 1952”, powinno być: „Wyd. polskie: Teofanes Wyznawca, Kronika w: Greckie i łacińskie źródła do najstarszych dziejów Słowian, cz. I, przeł. M. Plezia, Prace etnograficzne 3, Poznań-Kraków 1952, s. 147-160”. Błąd zasadniczy polega jednak na tym, że nie jest to w żadnym wypadku ,wyd. polskie”, lecz przekład odnoszących się do Słowian fragmentów dzieła Teofanesa. To samo dotyczy tejże s. 486 (lin. 7-8 od góry), gdzie widnieje następujący zapis: „Wyd. polskie: tegoż [= Teofilakt Symokatta], Historia w: Greckie i łacińskie źródła do najstarszych dziejów Słowian, cz. I, przeł. M. Plezia, Poznań-Kraków 1952”. Jest to, podobnie jak w przypadku Teofanesa, błąd, ponieważ M. Plezia na s. 101-117 zamieścił wyłącznie przekład tych fragmentów pracy Teofilakta, które odnoszą się ,do najstarszych dziejów Słowian".

Co więcej, w Bibliografii można znaleźć także jeszcze inne źródła historyczne, z tym że w przekładzie na język angielski, niemiecki czy francuski, które również powinny widnieć wyłącznie w Tekstach źródłowych. Oprócz niewłaściwego umiejscowienia, niestety nie uniknięto też kilku błędów w ich opisach bibliograficznych. 
Uważny Czytelnik może natknąć się również w omawianej Bibliografii na s. 497 (lin. 1-2 od góry) na pewną niejasność. Widnieje tam wyłącznie polski przekład znanej postmodernistycznej pracy E. Le Roy Laduriego (ur. 19 VII 1929), Montaillou, wioska heretyków, którą Autor cytuje w swojej pracy na stronie 453 (przyp. 5). W tejże Bibliografii brakuje opisu bibliograficznego przekładu tej pracy na język angielski, z którego korzystał P. Heather. Ponadto polski wydawca zamieścił w Bibliografii rok 1998 jako datę wydania polskiego przekładu rzeczonej pracy E. Le Roy Laduriego, gdy tak naprawdę książka ta została opublikowana w 1988 r. bez kolejnych jej wznowień.

Jeszcze inny problem stanowią w recenzowanej pracy pewne braki w Indeksie osobowym czy Indeksie geograficznym. Na s. 413 (lin. 11 od góry) została przytoczona biblijna postać Szymona Maga, której zabrakło w owym Indeksie osobowym. Natomiast na s. 400 (lin. 8 od góry, lin. 11 od góry, lin. 14 od góry i lin. 19 od góry), a także na s. 477 (lin. 19 od góry), jest mowa o starożytnym porcie rzymskim „Portus”, założonym przez cesarza Klaudiusza (1 VIII 10 - 13 X 54, cesarz od 24 I 41), wokół którego z czasem powstało oddzielne miasto, będące nawet siedzibą biskupią. Miasto „Portus” zostało zatem przytoczone pięciokrotnie na przestrzeni całej książki, jednak nie znalazło się w Indeksie geograficznym.

W polskim przekładzie najnowszej publikacji P. Heathera nie zabrakło również niewielkich „wpadek” o różnej konotacji. Na s. 36 (lin. 2 od góry) jest: ,świtę”, powinno być: ,świtą”. Na s. 41 (lin. 13 od dołu) jest: „dolce vita”, powinno być: ,dolce vita" (to samo na s. 201, lin. 6 od góry) (Autor zwykle dla łaciny stosuje kursywę). Na s. 51 (lin. 10 od dołu) jest: „via Egnatia”, powinno być: „,via Egnatia" (to samo na s. 60, lin. 2 od dołu; s. 64, lin. 16 od dołu). Na s. 54 (lin. 13 od góry) jest: „status quo”, powinno być: „status quo” (to samo na s. 146, lin. 3 od góry; s. 151, lin. 15 od góry; s. 304, lin. 10 od dołu). Na s. 60 (lin. 10 od dołu) jest: „in blanco”, powinno być: ,in blanco”. Na s. 66 (lin. 17 od dołu) jest: „establishment”, powinno być: ,establishment" (to samo na s. 82, lin. 1 od dołu; s. 271, lin. 4 od dołu; s. 459, lin. 16 od góry). Na s. 79 (lin. 7 od dołu) jest: „,credo”, powinno być: „credo”. Na s. 84 (lin. 11-10 od dołu) jest: „(zwłaszcza w Brytanii) ${ }^{12}$.”, powinno być: „,(zwłaszcza w Brytanii) ${ }^{12}$.” (chodzi o niepotrzebną spację przed numerem przypisu). Na s. 99 (lin. 2 od dołu) jest: „de facto”, powinno być: „de facto" (to samo na s. 237, lin. 4 od dołu; s. 267, lin. 17 od dołu; s. 303, lin. 13 od góry; s. 325, lin. 1 od dołu; s. 347, lin. 14 od góry; s. 370, lin. 14 od góry; s. 433, lin. 10 od góry). Na s. 105 (lin. 16-17 od dołu) jest: „List papieża Leona do Flawiana”, powinno być: „List do Flawiana” (por. s. 344, lin. 17 od góry). Na s. 109 (lin. 9 od dołu) jest: „Momiglian”, powinno być: „Momigliano”. Na s. 112 (lin. 14 od góry) jest: „,persona grata”, powinno być: ,persona grata”. Na s. 128 tytuł załączonej mapy brzmi: „Iustiniana Prima / Carycyn Grad”, a powinno być: „Iustiniana Prima / Carycyn Grad” (to samo na s. 129, lin. 12 od góry; s. 132, lin. 8 od dołu; s. 390, lin. 12 od góry; s. 515, lin. 6 od góry). Na s. 133 (lin. 5 od dołu) jest: ,in flagranti”, powinno być: „, in flagranti”. Na s. 146 (lin. 17 od góry) jest: „dzisiejszych”, powinno być: „dzisiejszego”. Na s. 163 (lin. 14 od góry) jest: 
„Byzacjum”, powinno być: „Byzacena” (tak jak na s. 167, lin. 6 od dołu; s. 196, lin. 8 od dołu; s. 197, lin. 16 od góry; s. 511, lin. 20 od dołu). Na s. 167 (lin. 8 od dołu) jest: „carte blanche”, powinno być: „,carte blanche”. Na s. 172 (w załączonej mapie: Podbój pótnocnej Afryki) jest: „Ad Decimum”, powinno być: „Ad Decimum" (Autor nie stosuje kursywy dla miast o pisowni łacińskiej). Na s. 181 (lin. 16 od góry) jest: „via Flaminia”, powinno być: „via Flaminia”. Na s. 181 (lin. 14 od dołu) jest: „Montefertro”, powinno być: „Montefeltro” lub „Mons Feretri”. Na s. 185 (lin. 12 od dołu) jest: „,musili”, powinno być: ,musieli”. Na s. 198 (lin. 2 od góry) jest: „prosperity”, powinno być: „prosperita”. Na s. 198 (lin. 14 od dołu) jest: „Summa summarum”, powinno być: „Summa summarum”. Na s. 211 (lin. 7 od góry) jest: „dictum”, powinno być: „,dictum”. Na s. 214 (lin. 4-5 od góry) jest: „pro publico bono", powinno być: ,pro publico bono”. Na s. 214 (lin. 5 od dołu) jest: ,,a priori”, powinno być: „, a priori”. Na s. 219 (lin. 15-16 od dołu) jest: „par excellence”, powinno być: „par excellence”. Na s. 237 (lin. 7 od góry) jest: „Księga papieży”, powinno być: „Księga papieży”. Na s. 237 (lin. 4 od dołu) jest: „,de iure", powinno być: , de iure" (to samo na s. 267, lin. 16 od dołu; s. 370, lin. 14 od góry). Na s. 242 (lin. 17 od góry) jest: ,post factum”, powinno być: ,post factum”. Na s. 247 (lin. 7 od góry) jest: „Księga historii Franków”, powinno być: „Księga historii Franków”. Na s. 248 (lin. 15 od dołu) jest: „quasi-imperium”, powinno być: ,quasi-imperium”. Na s. 261 (lin. 4 od dołu) jest: „Patrimonium Sancti Petri”, powinno być: „Patrimonium Sancti Petri”. Na s. 269 (lin. 16 od góry) jest: „ad hoc”, powinno być: „ad hoc” (to samo na s. 433, lin. 7 od dołu). Na s. 274 (lin. 13 od dołu) jest: „fortissimo”, powinno być: ,fortissimo”. Na s. 313 (lin. 14 od góry) jest: „quasi-autonomicznymi”, powinno być: „quasi-autonomicznymi”. Na s. 314 (lin. 16 od dołu) jest: ,ab ovo”, powinno być: ,ab ovo”. Na s. 335 (lin. 7-8 od góry) jest: „Karol Wielki i papież Leon”, powinno być: „Karol Wielki i papież Leon”. Na s. 344 (lin. 17 od góry) jest: „List do Flawiana”, powinno być: „List do Flawiana”. Na s. 357 (lin. 6 od dołu) jest: ,patrimonium Sancti Petr”, powinno być: „Patrimonium Sancti Petri”. Na s. 362 (lin. 17-18) jest: „Historia Kościoła angielskiego”, powinno być: „Historia Kościoła angielskiego”. Na s. 369 (lin. 2 od dołu) jest: „Nihil novi”, powinno być: „Nihil novi”. Na s. 371 (lin. 14 od góry) jest: „sacrum”, powinno być: „sacrum”. Na s. 371 (lin. 14 od góry) jest: „profanum”, powinno być: „profanum”. Na s. 373 (lin. 9-11 od góry) jest: „Projekt correctio musiał się zatem zacząć od ksiąg i na synodach reformatorskich z 812 roku (o czym szerzej za chwilę) ustalano od których.”, powinno być: „Projekt correctio Karola Wielkiego musiał się zatem zacząc od ksiagg, a synody reformatorkie z 812 roku (o czym szerzej za chwilę) były gotowe na bardziej szczegółowe ustalenia w stosunku do każdej z nich.” (por. z tekstem oryginału: „Charlemagne's project of correctio had to start with the books, therefore, and the reform councils of 812 (to which we'll return in a moment) were ready to be more specific about which ones." - P. Heather, The Restoration of Rome: Barbarian popes \& Imperial pretenders, Oxford 2013, 336). Na s. 373 (lin. 16 od góry) jest: „O opiece pasterskiej”, powinno być: „O opiece pasterskiej”. Na s. 392 (lin. 8 od góry) jest: 
„scryptoria”, powinno być: „skryptoria”. Na s. 404 (lin. 6 od dołu) jest: „stricte”, powinno być: „stricte” (to samo na s. 437, lin. 9 od dołu). Na s. 413 (lin. 12-13 od góry) jest: ,,apostołów Piotra i Pawła”, powinno być: ,apostołów Piotra i Jana” (por. z tekstem Dz 8, 14-24). Na s. 423 (lin. 5 od dołu) jest: „status quo ante”, powinno być: ,status quo ante” (tak jak na s. 83, lin. 4 od góry). Na s. 438 (lin. 1 od góry) jest: „Harmonia niezgodnych kanonów”, powinno być: „Harmonia niezgodnych kanonów" (tak jak na s. 439, lin. 15 od góry). Na s. 513 (lin. 2 i 7 od góry) jest: „San Apolinare”, powinno być: „San Apollinare”. Na s. 513 (lin. 9 od góry) jest: „Senigalli”, powinno być: „Senigallii”. Na s. 514 (lin. 1 od góry) jest: „Henryk IV I hrabina Matylda”, powinno być: „Henryk IV i hrabina Matylda”. Na s. 515 (lin 2 od góry) jest: „Genealogia Amalów”, powinno być: „Drzewo genealogiczne Amalów" (tak jak jest na s. 24 w tytule załączonej mapy).

Podsumowując, należy z naciskiem podkreślić, że narracja książki P. Heathera jest prowadzona w sposób niezwykle wciagający i rzeczowy. Autor „czaruje” Czytelnika nie tylko barwnym i miejscami dowcipnym językiem, dzięki czemu dużo łatwiej zapamiętać nawet szczegóły rozprawy, ale również licznymi ciekawymi hipotezami interpretacyjnymi, które są wynikiem wnikliwie przeprowadzonej hermeneutyki źródeł historycznych. Polski przekład dobrze oddaje te cechy oryginału, oferując jednocześnie Czytelnikowi kilka ciekawych ,uzupełnień", które wraz z bogatą szatą graficzną Odrodzenia Rzymu wręcz zachęcają do sięgnięcia po tę pozycję. Wydaje się również, że bardzo dobrym rozwiązaniem było zrezygnowanie z umieszczenia w Spisie treści tytułów podrozdziałów, które znalazły się praktycznie w każdym rozdziale książki. W ten sposób uzyskano klarowność i jasność Spisu, unikając tym samym niebezpieczeństwa natłoku drugorzędnych informacji.

W ostatecznym rozrachunku, pomimo znacznej ilości różnorodnych usterek, których nie udało się uniknąć polskiemu wydawcy najnowszej publikacji P. Heathera, warto tę pozycję polecić przede wszystkim entuzjastom historii starożytnego Rzymu i Bizancjum, historii powszechnej wieków średnich oraz historii Kościoła.

Damian Kalinowski - Lublin, KUL

\section{Stanisław KALINKOWSKI, Scire Latine. Język taciński. Podręcznik dla alumnów i studentów teologii, Lingua Sacra 3, Warszawa 2014, Wydawnictwo „Verbinum”, ss. 370.}

Dla humanistyki ostatnie lata w Polsce nie należały niestety do „lat thustych” w ogóle, a przedmiotów klasycznych w szczególności. Szkół nauczających klasycznego języka greckiego trzeba by szukać ze świeczką. $Z$ nauczania zaś łaciny, szkoły wycofywały się, gdyż był to dla nich kosztowny, a dla uczniów podobno jedynie nieprzydatny obowiązek. Według danych Ministerstwa Edukacji Narodowej, łaciny w Polsce uczy się ok. 1,5\% uczniów szkół średnich ogólnokształcących. 